Terbit setiap Januari dan Juli

$$
\text { Pll Al-Turas }
$$

ISSN : 0853-1692

MIMBAR SEJARAH, SASTRA, BUDAYA, DAN AGAMA

website : bit.ly/buletinalturas

\title{
Jenis Implikatur Percakapan antara Pramuniaga Mobil Mitsubishi dengan Konsumen di Kota Padang
}

\author{
Betari Anindya \\ Program Studi Linguistik, Universitas Andalas \\ email: betarianindya@gmail.com \\ Ike Revita \\ Program Studi Linguistik, Universitas Andalas \\ email: ikerevita30@gmail.com \\ Gusdi Sastra \\ Program Studi Linguistik, Universitas Andalas \\ email: sastrabudaya84@gmail.com
}

\begin{abstract}
Abstrak
Penelitian ini bertujuan untuk menjelaskan jenis implikatur yang terdapat pada percakapan antara pramuniaga mobil Mitsubishi dengan konsumen di Kota Padang. Berdasarkan cara dan prosedur analisis datanya, penelitian ini menggunakan pendekatan kualitatif, karena menghasilkan data deskriptif berupa kata-kata tertulis atau lisan. Data dalam penelitian ini adalah tuturan implikatur antara pramuniaga mobil Mitsubishi dengan konsumen di Kota Padang. Data yang dikumpulkan menggunakan metode simak. Metode ini diwujudkan dengan menggunakan teknik dasar dan teknik lanjutan. Teknik dasar yang digunakan adalah teknik sadap. Sedangkan teknik lanjutan digunakan adalah teknik simak bebas libat cakap, teknik rekam, dan teknik catat. Berdasarkan hasil analisis ditemukan 4 jenis implikatur yang digunakan dalam percakapan antara pramuniaga mobil Mitsubishi dengan konsumen di Kota Padang, yaitu 1) implikatur percakapan umum, 2) implikatur percakapan khusus, 3) implikatur percakapan skala, 4) dan implikatur percakapan konvensional.

Kata kunci: Implikatur, Perakapan, Pramuniaga Mobil, Konsumen, Mitsubishi.

Abstract

This study aims to explain types of implicatures found in the conversations between Mitsubishi car's sales and consumers in Padang City. Based on the method and procedure of data analysis, this study uses a qualitative approach because it generates descriptive data in the form of written or oral words. The data in this study is implicature speech between Mitsubishi car's sales and consumers in Padang City. Data is collected by using observational method. This method is realized by using basic and advanced techniques. The basic technique used is tapping technique, while the advanced techniques used are the process of non participation observational technique, recording technique, and note taking techniques. From the results of analysis, it is found 4 types of implicatures used in conversations between Mitsubishi car's sales and consumers in Padang City. There are 1) general conversational implicatures, 2) special conversational implicatures, 3) scale conversational implicatures, 4) and conventional conversational implicatures.
\end{abstract}

Keywords: Implicature, Conversational, Car's Sales with Consumers, Mitsubishi. 
Betari Anindya, Ike Revita, dan Gusdi Sastra:

Jenis implikatur percakapan antara pramuniaga mobil Mitsubishi dengan konsumen di Kota

\section{A. Pendahuluan}

Konsep implikatur percakapan pertama kali dikemukakan oleh Paul Grice pada tahun 1975 dalam artikelnya yang berjudul "Logic and Conversation". Grice (1975) menyatakan implikatur adalah sebuah tuturan yang dapat mengimplikasikan proposisi yang bukan merupakan bagian dari tuturan tersebut. ${ }^{1}$

Sementara itu, Wijana mengemukakan bahwa implikatur adalah hubungan antara tuturan dengan yang disiratkan dan tidak bersifat semantik, tetapi kaitan keduanya hanya didasarkan pada latar belakang yang mendasari kedua proposisinya. ${ }^{2}$ Berbeda dengan Levinson (1983) menyebutkan bahwa implikatur sebagai salah satu gagasan atau pemikiran terpenting dalam pragmatik.

Berdasarkan hal tersebut maka implikatur dapat disimpulkan sebagai bentuk tindakan yang digunakan penutur dan lawan tutur untuk menyampaikan tuturan yang mengandung maksud-maksud tertentu dan berbeda dengan struktur bahasa yang digunakan. Dibalik sebuah tuturan implikatur terdapat sebuah implikasi. Implikasi tersebut diartikan sendiri oleh lawan tutur meskipun penutur tidak menjelaskan maksud dari tuturan yang sebenarnya.

Makna tersirat yang diakibatkan dari adanya perbedaaan antara tuturan dengan implikasiya, kadang-kadang dapat menyulitkan penutur untuk memahami maksud suatu tuturan. ${ }^{3}$ (Mulyana;2001). Berdasarakan hal itu maka implikatur dipakai untuk menerangkan makna implisit dibalik apa yang diucapkan atau dituliskan

\footnotetext{
${ }^{1}$ H. Paul Grice, Ligic and Conversation in P. Cole and J.L Morgan Eds, Syntax and Semantics (New York: Academic Press, 1975).

2 I Dewa Putu Wijana, Dasar-Dasar Pragmatik (Yogyakarta: Andi, n.d.), 38.
}

sebagai suatu yang diimplikasikan. Dalam hal ini implikatur sebagai salah satu aspek kajian pragmatik memiliki perhatian utama dalam pemakaian bahasa untuk mempelajari maksud atau ucapan sesuai dengan konteksnya.

Adapun Igwedibia (2017) telah melakukan penelitian 'Grice's Conversational Implicature: A Pragmatics Analysis od Selected Poems of Audry Lorde' untuk menemukan sejauh mana implikatur percakapan dan maksim kerjasama dapat diterapkan dalam pembacaan puisi Audre Lorde. Selanjutnya, Wahyuningsih dan Rafli (2017) meneliti tentang "Implikatur Percakapan dalam Stand Up Comedy 4" guna memperoleh pemahaman mendalam mengenai jenis implikatur, sifat implikatur dan maksim kerja sama dalam Stand $U p$ Comedy 4 Indonesia. Hal ini menjelaskan bahwa penelitian mengenai pragmatik khususnya implikatur semakin berkembang dan menarik perhatian peneliti bahasa.

Dalam penggunaannya makna tersirat seperti hal di atas dapat ditemukan dalam bidang-bidang tertentu, seperti; dalam iklan, budaya, berita, politik, hukum, dan perniagaan. Dalam sebuah lingkungan perniagaan juga terdapat bagian-bagian tertentu seperti, front office, accounting, housekeeping, engineering, pramuniaga, dan marketing. Berdasarkan hal tersebut, maka dalam penelitian ini penulis fokus membahas mengenai pramuniaga mobil Mitsubishi di Kota Padang.

Pramuniaga mobil dipilih karena cenderung lebih aktif dalam melakukan percakapan kepada konsumen dalam melakukan penjualan atau pemasaran.

3 Mulyana, Implikatur Dalam Kajian Pragmatik DIKSI 8 (9): 53-63. Dalam Sebuah Jurnal Ebookbrowse.Com Diakses 13 Desember 2017, Pukul 09.00 WIB. 
Sementara itu, merek Mitsubishi dipilih karena Mitsubishi adalah salah satu merek mobil yang paling diminati di Indonesia. ${ }^{4}$

Dalam melakukan promosi terhadap produk yang dijual pramuniaga mobil suatu perusahaan cenderung meninggikan nilai produknya sendiri dibandingkan dengan produk perusahaan lain. Terkadang hal ini disampaikan dengan menggunakan ujaran bersifat pragmatis. Hal inilah yang dibutuhkan sebagai data penelitian. Penelitian ini dibatasi berdasarkan percakapan yang mengandung makna implisit pada percakapan antara pramuniaga dengan konsumen mobil yang menjelaskan jenis implikatur serta tuturan yang mengikutinya.

Mitsubishi adalah salah satu perusahaan jepang yang memproduksi kendaraan terutama mobil yang menggunakan logo tiga berlian merah. PT. Andalas Berlian Motor merupakan dealer resmi mobil merek Mitsubishi yang ada di Kota Padang. Dealer ini berlokasi dijalan Jl. By Pass Km 11 Kota Padang. Di kota Padang dealer ini memiliki beberapa cabang yang terletak di J1. Niaga dan Jl. Khatib Sulaiman kota Padang.

$$
\text { Gudang Mitsubishi ini }
$$
memproduksi beberapa macam mobil merek Mitsubishi baik untuk pemakaian pribadi (keluarga) ataupun niaga atau bisnis oleh perusahaan. Perusahaan ini bergerak dibidang penjualan berbagai jenis kendaraan merek Mitsubishi baik kendaraan keluarga (jenis Lancer, Grandis, Maven, Kuda, Pajero dan Triton). Sedangkan, jenis mobil untuk pemakaian niaga meliputi Mitsubishi Fuso, L 300, L 200, Super Pick Up. Selain itu, perusahaan Mitsubishi juga bergerak dibidang penjualan suku cadang

\footnotetext{
4 Aito Harry Budiawan, "Mobil Mobil Terlaris Di Awal Tahun 2018 Dalam Sebuah Berita Otomotif.," metrotvnews.com diakses pada tanggal 13 Mei, Pukul 08.00 WIB 2018, parag 5.
}

serta pusat perbengkelan untuk servis, pemeliharaaan dan perbaikan segala jenis kendaraan merek Mitsubishi.

Saat ini perusahaan Mitsubishi Indonesia mendapatkan respon positif dari masyarakat terhadap salah satu produknya yaitu Mitsubishi Xpander (Prayogi, 2018, parag.1). Hal ini menjelaskan dengan adanya produk Mitsubishi Xpander maka merek Mitsubishi menjadi sangat diminati oleh masyarakat. Tingginya minat masyarakat terhadap salah satu produk Mitsubishi adalah salah satu hasil upaya pramuniaga dalam menjual serta mempromosikan produk perusahaan tersebut. Berdasarkan hal tersebut peneliti tertarik untuk melihat fenomena kebahasaan yang terjadi antara pramuniaga Mitsubishi dengan konsumen.

Bidang pramuniaga dalam melaksanakan kegiatan penjualan dan pemasaran tentu juga menggunakan bahasa dalam berkomunikasi dengan konsumen. Pramuniaga mobil Mitsubishi di Kota Padang (selanjutnya disingkat dengan PMM) dalam berkomunikasi menggunakan bahasa sebagai media untuk menyalurkan ide atau gagasan guna menarik perhatian konsumen terhadap produk yang dijual atau dipasarkan. Dalam hal ini biasanya PMM di Kota Padang akan melakukan pemasaran dengan melakukan percakapan dengan konsumennya.

Menurut Gumperz dalam Nugraheni percakapan merupakan suatu bentuk aktivitas kerjasama yang berupa interaksi komunikatif. ${ }^{5}$ Percakapan adalah interaksi verbal yang berlangsung secara tertib dan

\footnotetext{
5 Yunita Nugraheni, "Analisis Implikatur Pada Naskah Film Harry Potter and The Goblet of Fire.," Semarang Universitas Muhammadiyah, 2010, 390.
} 
Betari Anindya, Ike Revita, dan Gusdi Sastra:

Jenis implikatur percakapan antara pramuniaga mobil Mitsubishi dengan konsumen di Kota

teratur yang melibatkan dua pihak atau lebih guna mencapai tujuan tertentu ${ }^{6}$

Percakapan antara konsumen dengan PMM di Kota Padang biasanya dilakukan secara face to face (berhadapan langsung) dengan menggunakan dua bahasa yaitu, bahasa Indonesia dan bahasa daerah. Sebagian karyawan PMM di Kota Padang cenderung menggunakan bahasa daerah dalam berkomunikasi dengan konsumen guna menciptakan suasana yang nyaman. Adapun sebagiannya cenderung menggunakan bahasa Indonesia guna menciptakan suasana formal. Hal ini juga bergantung kepada konsumen, sebab seorang pramuniaga cenderung memberikan kenyamanan saat berkomunikasi dengan konsumennya.

Dalam berlangsungnya proses percakapan antara karyawan PMM di Kota Padang dengan konsumen terkadang maksud yang dituturkan mempunyai arti langsung dan tidak langsung. Hal ini sama dengan percakapan yang biasa terjadi namun, konteks serta hal yang diperbincangkan akan berbeda. Pada umumnya percakapan yang terjadi juga sering melanggar kaidah-kaidah dalam percakapan. Hal inilah yang mengakibatkan timbulnya sesuatu yang terimplikasi dalam penggunaan bahasa. Berdasarkan hal tersebut, untuk memahami lebih lanjut tentang makna yang tersirat atau dimaksudkan dalam tuturan konsumen dengan PMM di Kota Padang diperlukan sebuah penelitian berdasarkan teori implikatur.

\section{B. Metode Penelitian}

Data merupakan bahan jadi penelitian. Sebagai bahan jadi penelitian, data dapat diterjemahkan sebagai objek

\footnotetext{
${ }^{6}$ Rustono, Pokok-Pokok Pragmatik (Semarang: CV IKIP Semarang Press, 1999), 48.
}

ditambah konteks. Jadi, terkait dengan penelitian yang akan dilakukan maka data dalam penelitian ini adalah tuturan pragmatis antara PMM dan $\mathrm{K}$ yang mengandung implikatur. Selanjutnya, Sudaryanto menyatakan bahwa data memiliki sumber data. $^{7}$ Sumber data tersebut terbagi atas dua, yaitu sumber data lokasional dan sumber data substantif. Untuk itu yang menjadi sumber data lokasional adalah pramuniaga mobil Mitsubishi dan konsumen. selanjutnya, yang menjadi sumber data substantif adalah segala teks percakapan antara pramuniaga mobil Mitsubishi dengan konsumen di Kota Padang.

Data penelitian diambil dari percakapan antara pramuniaga mobil Mitsubishi dengan konsumen di Kota Padang. Selanjutnya, penelitian dilakukan di PT. Andalas Berlian Motors Padang dengan beberapa cabang perusahaan yang berada di Jl. Baypas, Niaga, dan Khatib Sulaiman. Untuk pengumpulan data dilakukan pada tiga tempat tersebut dengan prosedur yang head office berikan.

Adapun prosedur yang diberikan dengan menyerahkan peneliti kepada salah satu supervisor (pengawas) PT. Andalas Berlian Motor guna membantu peneliti dalam mengumpulkan data dilapangan. Pengambilan data sesuai instruksi yang diberikan oleh pengawas yaitu dengan ikut serta bersama pramuniaga mobil Mitsubishi dalam melayani konsumen yang ingin membeli mobil. Dalam hal ini, supervisorlah yang menentukan pramuniaga yang akan membantu peneliti dalam proses pengambilan data.

Untuk pengumpulan data digunakan metode simak. Berikut merupakan beberapa langkah yang peneliti lakukan dalam

7 Sudaryanto, Metode Linguistik: Ke Arah Memahami Metode Linguistik (Yogyakarta: Gadjah Mada University Press, 2015). 
penyediaan data; langkah pertama yang penulis lakukan adalah menyadap percakapan yang terjadi antara pramuniaga dengan konsumen dengan menggunakan teknik sadap yang merupakan bagian dari teknik dasar dari metode simak. Langkah kedua dilanjutkan dengan menyimak dan memperhatikan penggunaan bahasa yang terjadi antara PMM dengan konsumen yang menggunakan teknik lanjutan simak bebas libat cakap. Langkah terakhir adalah melakukan penyaringan data dengan mengelompokkan ke dalam jenis dan makna implikatur yang terdapat dalam percakapan yang terjadi serta mencatat hasil penyimakan terhadap data percakapan yang terjadi dengan menggunakan teknik rekam dan catat.

Metode yang digunakan dalam menganalisis data penelitian ini adalah metode padan. Dimana alat penentu dari metode tersebut adalah, yaitu metode referensial, metode translational, dan metode pragmatis. Analisis dilakukan dengan cara mengkalasifikasikan tuturan yang menjadi data berdasarkan jenis-jenis implikatur yang dikemukakan percakapan oleh Yule (1996) yaitu implikatur umum, implikatur khusus, implikatur skala dan implikatur konvensional.

\section{Hasil dan Pembahasan}

Jenis implikatur pada percakapan pramuniaga mobil Mitsubishi diklasifikasikan berdasarkan jenis-jenis implikatur dengan menggunakan teori yang dikemukakan oleh Yule. ${ }^{8}$ Jenis-jenis implikatur tersebut terdiri dari implikatur percakapan umum, implikatur percakapan khusus, implikatur percakapan skala, dan implikatur percakapan konvensional.

\section{Implikatur percakapan umum}

Implikatur percakapan umum adalah implikatur yang kehadirannya dalam sebuah percakapan tidak memerlukan konteks khusus. ${ }^{9}$ Dengan kata lain dalam implikatur umum tidak ada latar pengetahuan khusus yang diminta untuk membuat kesimpulan. Adapun beberapa implikatur percakapan umum yang ditemukan dalam percakapan pramuniaga mobil Mitsubishi dengan konsumen di Kota Padang diantaranya adalah sebagai berikut.

Dialog 6

PMMP Baa Pak oto Xpander yang patang tu?

'Bagaimana mobil Mitsubishi Xpander yang kemarin Pak?'

KL Iko Buk aa, nio nanyo DPnyo baa caro sistemnyo tu?

Begini Buk, mau menanyakan bagaimana prosedur uang muka?'

PMMP Apak nio cash atau kredit rencananyo?

'Bapak rencananya mau pembayaran tunai atau kredit ?'

KL

\section{Cash bisa juo kalau}

kreditkan pitih ko bisa dilarian ka nan lain dulu, nyo baa caro angsurannyo tu Buk?

'Tunai bisa juga, kalau kreditkan uangnya bisa digunakan untuk yang lain dulu. Bagaimana cara angsurannya Buk?'

PMMP Kalau kredit beko bisa diituang samo urang leasingnyo Pak. Apak nio DP bara?

\footnotetext{
${ }^{8}$ George Yule, The Study of Language (Cambridge: Cambridge University Press, 2010). 
Betari Anindya, Ike Revita, dan Gusdi Sastra:

Jenis implikatur percakapan antara pramuniaga mobil Mitsubishi dengan konsumen di Kota

'Kalau kredit nanti bisa diitung sama orang leasingnya Pak. Bapak ingin uang muka berapa?'

Data di atas menunjukkan adanya permintaan barang. Pragmatik merupakan suatu kajian tindak tutur permintaan bahasa.

${ }^{10}$ Berangkat dari pemahaman ini, data yang dipakai dalam kajian ini merupakan tindak tutur lintas bahasa

Seorang konsumen datang ke ruang pameran mobil dan menghampiri salah satu pramuniaga mobil Mitsubishi yang ia kenal. Dalam percakapan ini penutur dan lawan tutur sebelumnya sudah pernah bertemu. Ia hendak menanyakan harga mobil Mitsubishi yang diminatinya.

Tuturan ini merupakan percakapan yang dituturkan oleh seorang PMMP kepada KL. Dialog tersebut telah melanggar maksim kuantitas, yang mana tanggapan KL atas pertanyaan PMMP mengenai sistem pembelian mobil terlalu informatif sehingga percakapan menjadi kurang efektif. Dalam hal ini, pelanggaran maksim kuantitas menyebabkan terjadinya sebuah implikatur percakapan.

Yule (1996) menyatakan bahwa penturlah yang menyampaikan makna lewat implikatur dan pendengarlah yang mengenali makna-makna yang disampaikan lewat interferensi itu. Tuturan 'Cash bisa juo kalau kreditkan pitih ko bisa dilarian ka nan lain dulu' merupakan sebuah implikatur yang disampaikan oleh KL (penutur) kepada PMMP (lawan tutur). Tuturan di atas dapat dikelompokkan kepada implikatur percakapan umum karena tidak dibutuhkan latar belakang pengetahuan khusus untuk menyimpulkan maksud yang ingin disampaikan oleh KL.
Jika dikaitkan kepada konteks percakapan maka tidak terlihat antara KL dan PMMP sama-sama memiliki konteks pengetahuan khusus mengenai apa yang sedang mereka bicarakan. Dalam hal ini terlihat bahwa PMMP (lawan tutur) mengenali makna atau maksud yang disampaikan oleh KL yang ditandai dengan tanggapan yang diberikan oleh PMMP berupa tuturan 'Kalau kredit beko bisa diituang samo urang leasingnyo Pak'. Berdasarkan tanggapan tersebut maka dapat disimpulkan bahwa lawan tutur memahami maksud yang ingin disampaikan oleh penutur. Setiap satuan bahasa memiliki makna. ${ }^{11}$ Berikut ini contoh dialognya Dialog 7

KL

DP paliang randahnyo bara ko Buk?

'Uang muka paling rendahnya berapa ini Buk?'

PMM Paliang randah biasonyo tujuah puluah Pak, tujuah puluahanlah paliang randah bana ma 'Paling rendah biasanya tujuh puluh juta rupiah Pak, tujuh puluh jutaanlah paling rendah sekali'

KL Tujuah puluah

'Tujuh puluh juta rupiah'

PMM Iyo 'Iya'

KL Jadi, kalau tujuah puluah angsurannyo salamo 36 bulan, bara tibonyo tu buk?

'Jadi, kalau tujuh puluh juta selama 36 bulan, berapa angsurannya Buk?'

\section{PMM Kok alah pasti unitnyo beko} diituangan dek leasing lai Pak

\footnotetext{
${ }^{10}$ Ike Revita, Pragmatik (Kajian Tindak Tutur Permintaan Lintas Bahasa (Padang, 2013).
}

${ }^{11}$ C.K. Odgen and L.A Richards, The Meaning of Meaning (London: ARK Paperbacks, 1923). 
'Jika mobilnya sudah pasti nanti dihitung oleh pihak leasing Pak'

KL Oh gitu Buk

'Oh begitu Buk'

Dialog 7 di atas merupakan bagian dari percakapan pada data $6 . \mathrm{K}$ dalam percakapan ini melontarkan beberapa pertanyaan untuk memastikan mobil yang ia inginkan. Salah satunya adalah dengan menanyakan harga mobil Mitsubishi Xpander kepada PMMP. PMMP menanggapi pertanyaan $\mathrm{K}$ dengan meminta $\mathrm{K}$ untuk memastikan mobil yang akan dibelinya. Artinya antara pembeli dan penjual ada unsur percakapan yang sangat penting bagi keduanya. ${ }^{12}$

Tanggapan PMMP telah melanggar maksim kerja sama yang mana PMM pada percakapan tidak memberikan informasi yang cukup terhadap pertanyaan yang diberikan oleh KL. PMMP tidak memberikan jawaban yang pasti mengenai harga angsuran mobil selama 36 bulan. Dalam hal ini maka PMMP telah melanggar sebuah maksim kerja sama yaitu kuantitas. Hal inilah yang menyebabkan timbulnya sebuah implikatur.

Tanggapan PMMP terhadap pertanyaan yang disampaikan oleh KL pada dialog 7 merupakan bentuk dari implikatur percakapan umum yang disampaikan oleh PMMP kepada KL. Tuturan 'Kok alah pasti unitnyo beko diituangan dek leasing lai Pak' dapat dikategorikan kepada bentuk implikatur percakapan umum karena pada tuturan tidak ditemukan adanya konteks pengetahuan khusus untuk menjelaskan makna tambahan yang disampaikan oleh PMMP. Sesuai dengan dialog 6 antara KL dan PMMP sama-sama tidak memiliki konteks pengetahuan khusus mengenai apa yang dibicarakan.

Dialog 11

KL

Nyo lai lapang?

'Mobilnya luas?'

PMMP Lah bisa lalok di balakang Pak, tampek duduak dibalakangnyo se lah sliding bisa dimaju mundurkan

'Sudah bisa tidur di belakang Pak, tempat duduk di belakang saja sudah sliding dapat dimajumundurkan'.

KL Yang di tangah?.Yang dibalakang bana?

'Yang di tengah?.Yang paling belangkang?'

PMMP Iyo, yang di balakang bana biaso se Pak.

'Iya, yang dibelakang sekali biasa saja Pak'

KL dengan PMMP membahas mengenai spesifikasi mobil Mitsubishi Xpander. Pada data di atas terjadi percakapan yang mana KL menanyakan mengenai interior mobil Mitsubishi Xpander. Selanjutnya, PMMP menanggapi dengan memberikan informasi sesuai yang dibutuhkan KL.

Setelah dilakukan analisis terhadap dialog 11, Dialog di atas melanggar maksim kuantitas dan maksim cara. Hal ini terlihat dari jawaban PMMP terkait pertanyaan yang dilontarkan oleh KL terlalu informatif sehingga tidak jelas dan percakapan yang terjadi menjadi tidak efektif. Tuturan tersebut akan menjadi efektif bila antara KL dan PMMP tidak melanggar maksim kerja sama. Pelanggaran

12 Nanda, "Conversational Implicature of the Presenters in Take ME Out Indonesia," Conaplin Journal Vol. 1 No. 2 (n.d.): Hlm 120-138. 
Betari Anindya, Ike Revita, dan Gusdi Sastra:

Jenis implikatur percakapan antara pramuniaga mobil Mitsubishi dengan konsumen di Kota

maksim kerja sama inilah yang menyebabkan terjadinya implikatur.

Implikatur ini terlihat pada tuturan yang disampaikan oleh PMMP kepada KL. Dialog 11 di atas mengandung implikatur percakapan umum. Berdasarkan percakapan yang telah terjadi tuturan 'lah bisa lalok di balakang Pak, tampek duduak dibalakangnyo se lah sliding bisa dimaju mundurkan' tidak membutuhkan konteks khusus untuk menjelaskan makna tambahan yang dimaksud oleh PMMP. Antara KL dengan PMMP sama-sama tidak memiliki latar belakang pengetahuan khusus sehingga tuturan tersebut dapat dikelompokkan kepada implikatur percakapan umum. Hal tersebut terlihat pada kalimat 'lah bisa lalok dibalakang Pak'.

Dialog 30

K2 Jadi, pas kita deal nanti talang airnya dipasangkan?

'Jadi, saat kita sudah sepakat nanti talang airnya dipasangkan?'

PMM Aduh Pak, gimana lagi tapi buat bapak kaca film sudah kami pasangkan belum lagi diskon. Ini yang bawa Ibuk atau Bapak?

'Aduh Pak bagaimana lagi tapi untuk Bapak kaca film sudah kami pasangkan belum lagi diskon. Ini yang membawa Ibuk atau Bapak?'

K1 Langsung ibuk yang bawa

'Ibuk yang langsung menyetir'

Sepasang suami istri datang ke ruang pameran mobil Mitsubishi untuk membayar uang muka mobil yang akan dibelinya. Dalam hal ini PMM memberikan bonus berupa kaca film dan diskon atas pembelian mobil Mitsubishi Xpander K. Pada dialog
30 terlihat bahwa $\mathrm{K}$ menginginkan bonus berupa talang air kepada PMM.

Adapun PMMP menanggapi permintaan K dengan tuturan 'Aduh Pak, gimana lagi tapi buat bapak kaca film sudah kami pasangkan belum lagi diskon. Ini yang bawa Ibuk atau Bapak?'. Berdasarkan tuturan ini maka terlihat bahwa PMM tidak mengikuti maksim kuantitas dengan memberikan tanggapan yang terlalu informatif sehingga tuturan menjadi kurang efektif.

Pelanggaran maksim kuantitas ini menyebabkan terbentuknya implikatur percakapan. Tuturan ini dikategorikan kepada implikatur percakapan umum. Selain melanggar maksim kuantitas, percakapan di atas juga memiliki latar belakang pengetahuan umum sehingga tidak diperlukan latar belakang pengetahuan khusus untuk membuat kesimpulan yang disampaikan. Hal ini terlihat dari percakapan bahwa K dan PMM sama-sama tidak memiliki latar belakang pengetahuan khusus.

Dialog 26

PMMP Pengen DP dibawah 100 ya, kalau nggak Adira ya MTF itu harganya hampir-hampir sama tapi kalau MayBank atau BCA karena Bank jadi lebih murah. 'Ingin uang muka dibawah 100 ya, kalau tidak Adira ya MTF itu harganya hampir-hampir sama tetapi kalau MayBank atau BCA karena itu Bank jadi lebih murah'

KL Dihitung dulu aja 'Dihitung saja dahulu'

PMMP Abang kasih aja panjar dulu nanti kita coba minta press bunganya, mudah-mudahan bisa. 
'Abang kasih saja panjar terlebih dahulu nanti kita coba untuk minta kurangi bunganya, mudah-mudahan bisa'.

KL Harus dipanjar berarti ya? 'Berarti harus dipanjar ya?'

\section{PMMP Mana tau nanti pas unit} datang tarifnya naikkan 'Bisa jadi nanti saat mobil datang tarifnya naikkan'

Seorang KL mendatangi PMMP dengan maksud ingin bernegosiasi mengenai uang muka untuk pembelian mobil. Dalam percakapan tersebut KL mengutarakan keinginannya membeli mobil dengan bunga yang kecil. KL ingin meminta solusi kepada PMMP leasing apa yang sebaiknya ia gunakan. PMM bertanggung jawab untuk menjamin kepuasan $\mathrm{K}$, untuk itu PMM berusaha memberikan informasi yang dibutuhkan oleh K. dalam percakapan terlihat PMM menyarankan beberapa leasing yang dapat digunakan pembiayaan mobil yang akan dibeli oleh $\mathrm{K}$. selain menyarankan beberapa leasing, PMMP juga menyarankan untuk memanjar mobil.

Dialog di atas melanggar maksim kerja sama yaitu maksim kuantitas. PMMP pada percakapan terlihat tidak mengikuti maksim kuantitas. Tuturan 8a 'Mana tau nanti pas unit datang tarifnya naikkan' tidak memberikan informasi yang cukup terhadap pertanyaan yang diberikan oleh KL sehingga percakapan menjadi kurang efektif. Adapun PMMP memberikan jawaban berupa tuturan berimplikasi sehingga membentuk sebuah implikatur percakapan.

Tuturan ini dapat dikategorikan kepada implikatur percakapan umum karena tidak membutuhkan konteks khusus untuk menjelaskan makna tambahan yang diberikan oleh PMMP. Dapat dilihat dalam percakapan bahwa PMMP dengan KP sama-sama tidak memiliki latar belakang pengetahuan khusus dalam berkomunikasi. Dialog 26 memiliki konteks umum yang berisikan tanggapan atas pertanyaan KL mengenai uang panjar mobil Mitsubishi.

\section{Implikatur percakapan khusus}

Implikatur ini terjadi dalam komunikasi konteks khusus. Implikatur khusus ini mempertimbangkan informasi-informasi yang terkait dengan peristiwa-peristiwa komunikasi konteks. Berikut merupakan hasil analisis data percakapan antara $\mathrm{K}$ dengan PMM yang mengandung implikatur percakapan khusus.

Dialog 27

PMMP Oh mau beli cash ya Pak? 'Oh mau membeli tunai ya Pak?'

KL Iya mau cash yang bayarkan Bank soalnya anak sayakan di Citylink.

'Iya mau tunai yang akan membayar Bank soalnya anak sayakan di Citylink'.

PMMP Sebentar ya Pak, yang makai kakak ya Pak?

'Sebentar ya Pak, yang menggunakan kakak ya Pak?'

KL Anak saya

'Anak saya'.

PMMP Bapak di Padang Pak?

'Bapak tinggal di Padang Pak?'

KL Iya di lubeg, di samping rumah makan Kartini. Tahu?

'Iya di Lubuk Begalung, di samping rumah makan Kartini. tahu?'

PMMP Saya dulu kuliah di UPI Pak

'Dulu saya kuliah di UPI Pak'

Seorang KL mendatangi ruang pameran mobil Mitsubishi hendak meninjau harga mobil yang ingin dibeli oleh anaknya. Selanjutnya, PMMP menghampiri KL 
Betari Anindya, Ike Revita, dan Gusdi Sastra:

Jenis implikatur percakapan antara pramuniaga mobil Mitsubishi dengan konsumen di Kota

hendak melayani dan menanyakan tujuan $\mathrm{K}$ tersebut. Dalam hal ini, KL menyampaikan tujuannya untuk mencari informasi harga mobil Mitsubishi.

PMM pada dialog di atas mencoba membangun kedekatan serta mendapatkan informasi KL. Untuk menjalin kerja sama serta hubungan yang baik seorang $\mathrm{P}$ harus mampu membangun kedekatan dengan $\mathrm{K}$. Untuk itu, PMM berusaha mencari informasi $\mathrm{K}$ dengan menanyakan beberapa hal terkait dengan informasi KL tersebut.

Pada data 27 berisikan percakapan mengenai tempat tinggal KL. KL tinggal dilubuk begalung yang tidak jauh dari rumah makan kartini. Dalam hal ini KL menanyakan apakah PMM tahu mengenai lokasi tempat tinggalnya. Selanjutnya, PMMP menanggapi dengan tuturan 'Saya dulu kuliah di UPI Pak' yang menyatakan bahwa ia adalah mahasiswi Universitas Putra Indonesia yang mana kampus tersebut berada tidak jauh berada dari rumah KL.

Setelah dilakukan analisis pada dialog 27 maka terlihat bahwa PMMP tidak mengikuti maksim relevan. Tanggapan yang diberikan oleh PMMP terlihat tidak relevan dengan tuturan sebelumnya. Untuk membuat tuturan relevan PMMP dapat menjawab dengan menyatakan bahwa ia 'tahu' atau 'tidak tahu'. Namun, PMMP menjawab dengan tuturan berimplikasi sehingga muncul tuturan implikatur.

Impliktur ini disampaikan oleh PMMP kepada KL. Dialog 27 dapat diklasifikasikan kepada implikatur percakapan khusus. Data tuturan di atas membutuhkan konteks khusus untuk membuat kesimpulan serta dibutuhkan latar belakang pengetahuan yang sama antara penutur dengan lawan tutur untuk mengetahui maksud dari dialog 27. KL dan PMMP sama-sama mengetahui konteks percakapan bahwa Universitas Putra Indonesia terletak tidak jauh dari lokasi tempat tinggal $\mathrm{KL}$ sehingga $\mathrm{KL}$ dapat memahami maksud tuturan yang ingin disampakan oleh PMM.

Dialog 31

PMMP Tunggu sebentar saya tanyakan dulu ya

'Tunggu sebentar saya tanyakan dulu ya'

K1 Iya

'Iya'

K2 Jadi, kalau sudah habis masa asuransi, saya masuk kemari tapi diskon kalau ga diskon saya tetap di sana.

'Jadi, kalau sudah habis masa asuransi, saya masuk kemari tetapi diskon kalau tidak diskon saya tetap disana'.

PAM Nanti bisa hubungi saya saja Pak

'Nanti bisa hubungi saya saja Pak'

Penutur dan lawan tutur pada data di atas membahas mengenai asuransi kendaraan. Pada percakapan sebelumnya PMMP menawarkan KL dan KP untuk melanjutkan asuransi. Adapun pada data di atas KP meminta pengurangan harga untuk penggunaan asuransi selanjutnya. Dalam hal ini sebelumnya PMMP sudah memberikan pengurangan harga untuk asuransi yang saat ini digunakan. Adapun PAM memberikan diskon karyawan kepada $\mathrm{K}$ tanpa sepengetahuan perusahaan asuransi tersebut.

Setelah dilakukan analisis terdapat pelanggaran maksim kerja sama pada dialog 31. PAM terlihat tidak mengikuti maksim relevansi saat percakapan berlangsung. Jawaban PAM tidaklah relevan terhadap pernyataan yang disampaikan oleh KP. Untuk membuat jawaban PAM menjadi relevan maka ia harus mengikuti maksim relevan dengan memberikan jawaban yang 
jelas bahwa ia akan diskon atau tidak sama sekali. Berdasarkan hal ini maka terbentuklah sebuah tuturan implikatur.

Implikatur pada dialog diatas disampaikan oleh PAM kepada $\mathrm{K}$. selanjutnya, implikatur ini berjenis implikatur percakapan khusus. Hal ini ditandai oleh tuturan 'Nanti bisa hubungi saya saja Pak'. Tuturan tersebut membutuhkan konteks khusus dalam membuat kesimpulan dan dibutuhkan latar belakang ilmu pengetahuan yang sama antara penutur dan lawan tutur untuk mengetahui maksud dari tuturan yang disampaikan. Percakapan terjadi pada konteks khusus yang mana antara penutur dan lawan tutur memiliki informasi yang sama-sama mereka ketahui bahwa saat ini PAM tidak dapat membicarakan hal tersebut saat itu.

Dialog 28

K3 Berarti harus yang Rp.

6.635.000,- itu ya?

'Berarti harus yang Rp.

6.635.000,- itu ya?'

PAM Iya kalau Ibu mau dikurangi

yang teroris juga bisa

'Iya kalau Ibu mau dikurangi

yang teroris juga bisa'

K3 Saya liat asuransi lain dululah yang lebih murah. Saya banyak nomor soalnya ini saya yang ngurus.

'Saya lihat asuransi lain dululah yang lebih murah. Saya banyak nomor soalnya saya yang ngurus ini'.

\section{PAM Kitakan ada diskon dari} kantor nanti

'Nanti kitakan ada diskon dari kantor'

Dalam percakapan ini terdapat 4 partisipan yang terdiri dari 3 konsumen dan seorang PAM.
Percakapan ini membicarakan tentang asuransi mobil yang mana $\mathrm{K}$ mencoba untuk menegosiasikan harga asuransi mobil yang ingin ia gunakan. Selanjutnya, PAM memberikan pengurangan harga tanpa diketahui perusahaan, yang mana konteks pada percakapan ini hanya diketahui oleh partisipan pada percakapakan yang sedang terjadi.

Data di atas merupakan tanggapan yang diberikan oleh PAM terhadap permintaan K. PAM telah mengabaikan maksim relevansi sehingga percakapan di atas menjadi tidak relevan. Hal tersebut karena PAM tidak memberikan tanggapan yang sesuai dengan pernyataan yang diberikan oleh K. Untuk membuat jawaban menjadi relevan $\mathrm{K}$ harus menyimpulkan bahwa PAM akan memberikan diskon untuknya. Pelanggaran maksim relevan tersebut menyebabkan terbentuknya implikatur.

Tuturan yang terdapat dalam percakapan antara PMM dan K ini berjenis implikatur khusus. Tuturan 'Kitakan ada diskon dari kantor nanti' membutuhkan konteks khusus untuk mengetahui maksud yang disampaikan. Konteks khusus dalam dialog 28 adalah PAM ingin memberikan asuransi karyawan kepada $\mathrm{K}$ dan tidak dapat membicarakan mengenai asuransi tersebut di ruang pameran motor. Berdasarkan data di atas $\mathrm{K}$ dan PAM sama-sama mengetahui situasi dan hal yang sedang mereka bicarakan sehingga $\mathrm{K}$ memahami maksud tuturan yang disampaikan oleh PAM.

\section{Implikatur percakapan konvensional.}

Implikatur jenis ini tidak didasarkan pada prinsip kerja sama atau maksimmaksim. Implikatur konvensional tidak harus terjadi dalam percakapan dan tidak bergantung pada konteks khusus untuk menginterpretasikannya. 
Betari Anindya, Ike Revita, dan Gusdi Sastra:

Jenis implikatur percakapan antara pramuniaga mobil Mitsubishi dengan konsumen di Kota

Namun, implikatur jenis ini diasosiasikan dengan kata-kata khusus dan menghasilkan maksud tambahan yang disampaikan apabila kata-kata itu digunakan. ${ }^{13}$ Berikut merupakan beberapa bentuk implikatur percakapan konvensional yang ditemukan pada percakapan $\mathrm{K}$ dengan PMM di kota padang.

Dialog 13

\section{KL Rencana kredit. Jadi, DPnyo paliang randah bara Buk? \\ 'Rencana kredit. Jadi, berapa uang muka paling rendahnya Buk?' \\ PMMP Paliang randah biasonyo 70 Pak 'Paling rendah biasanya 70 Pak'. \\ KL Ndak bisa kurang lai? \\ 'Tidak bisa kurang harganya lagi?' \\ PMMP Ketek DP tu gadang angsurannyo Pak}

'Kecil uang muka jadi besar angsurannya lagi Pak' 14

Tuturan di atas terjadi antara KL dengan PMMP di ruang pameran mobil Mitsubishi. KL dan PMMP bernegosiasi mengenai uang muka pembayaran mobil Mitsubishi Xpander yang akan dibelinya. Dalam hal ini KL mengharapkan uang muka yang kecil untuk pembelian mobil Mitsubishi Xpander. Untuk itu ia menyampaikan keinginannya agar PMM dapat memberikan saran mengenai hal tersebut.

Berdasarkan tanggapan yang diberikan maka tuturan 'Ketek DP tu gadang angsurannyo Pak' dapat dikelompokkan kepada implikatur percakapan konvensional. Hal ini karena tuturan tersebut tidak didasarkan pada

\footnotetext{
${ }^{13}$ Yule, The Study of Language, 78.
}

prinsip kerja sama melainkan diasosiasikan dengan kata-kata khusus untuk menghasilkan maksud atau makna tambahan yang disampaikan.

Dalam KBBI (2008) kata tu atau jadi memiliki arti langsung berlaku (dilakukan, dikerjakan); tidak batal. Kata 'tu' yang digunakan oleh PMMP dapat mengimplikasikan sesuatu yang bertolak belakang dengan yang diharapkan dalam percakapan. Berdasarkan konteks percakapan KL menginginkan harga terendah untuk uang muka mobil Mistubishi Xpander. Oleh karena itu maka dapat disimpulkan bahwa kata 'tu' memiliki makna yang mengimplikasikan sesuatu yang bertolak belakang dengan apa yang diharapkan dalam percakapan sehingga dapat diklasifikasikan kepada implikatur konvensional.

Dialog 14

KP Oh gitu. Jadi, kalau mode tu beko oto lai masuak asuransi Buk?

'Oh begitu. Jadi, kalau seperti itu nanti mobil dapat asuransi Buk?'

PMM Kok kredit aman beda jo cash Pak.

'Kalau kredit aman beda dengan tunai Pak'

KP Asuransinyo lai all risk tu Buk?

'Asuransinya all risk tidak Buk?'

PMM Lai, All risk Pak.

'Iya, all risk Pak'

Seorang KP menanyakan mengenai asuransi mobil kepada PMMP. KP ingin membeli mobil Mitsubishi Xpander dan ingin memastikan mengenai asuransi mobil tersebut. KP khawatir mobil tersebut tidak memiliki asuransi apabila terjadi kecelakaan. Untuk itu ia menanyakan

14 Gesit Prayogi, "Mitsubishi Indonesia Dapat Pesanan 3,8 Ribu Unit Xpander Dari Filipina,” 2018. 
mengenai asuransi kepada PMMP guna mendapatkan informasi terkait hal tersebut.

Tuturan di atas merupakan salah satu bentuk dari implikatur percakapan konvensional. Hal ini ditandai oleh tuturan 'Kok kredit aman beda jo cash Pak' merupakan bentuk tuturan implikatur konvensional. Menurut KBBI (2008) kata 'beda' pada tuturan di atas merujuk kepada makna konvensional yaitu sesuatu yang menjadikan berlainan (tidak sama) antara benda yang satu dan benda yang lain (KBBI, 2008). ${ }^{15}$ Kata 'beda' memiliki implikasi sesuatu yang bertolakbelakang. Dalam dialog di atas maka pembayaran kredit bertolak belakang dengan tunai. Dengan demikian maka dialog di atas dapat diklasifikasikan kepada implikatur percakapan konvensional.

Dialog 2

\section{K1 Manual Exceed aja yang ada? 'Mobil manual hanya Exceed yang ada?' \\ PMM Exceed, Glx, sama Gls Bang 'Exceed, Glx, dengan Gls Bang' \\ K2 Exceed tu tipe menengah yo 'Exceed itu mobil tipe menengah ya' \\ PMM Iya bang tapi urang banyak ambiak tipe Exceed yang manual sih bang makanya lama indennya \\ 'Iya bang tapi orang banyak memilih tipe Exceed yang manual makanya lama proses indennya'}

KL mendatangi ruang pameran mobil Mitsubishi bersama istri dan anaknya. Dalam hal ini $\mathrm{K}$ ingin membeli mobil Mitsubishi Xpander namun masih ragu untuk memilih tipe mobil yang tepat. Dari data di atas, terlihat bahwa $\mathrm{K}$ dengan PMMP sedang membahas mengenai tipe mobil Mitsubishi Xpander. K pada percakapan terlihat menanyakan mengenai mobil Mitsubishi Xpander tipe Exceed.

Berdasarkan tanggapan yang diberikan oleh PMM maka tuturan 'Iya bang tapi urang banyak ambiak tipe Exceed yang manual sih bang makanya lama indennya' merupakan tuturan implikatur. Dari tuturan tersebut terlihat ia mengimpilkasikan sesuatu pada tuturannya sehingga terbentuklah tuturan implikatur. Setelah dilakukan analisis terhadap tuturan di atas maka tuturan tersebut dapat dikategorikan kepada implikatur percakapan konvensional.

Hal ini ditandai dengan kata 'tapi' yang merujuk kepada makna konvensional. Kata 'tapi' menghasilkan maksud berimplikasi yaitu sesuatu yang bertolak belakang.

\section{Implikatur percakapan skala}

Implikatur jenis skala adalah implikatur yang maknanya berkaitan dengan ketidakpastian dan ketidakjelasan rujukan jumlah atau angka tertentu. Implikatur skala dapat ditandai dengan tidak menunjukkan jumlah tertentu dengan tidak pasti atau menggunakan kode-kode tertentu. Implikatur skala biasanya dapat diidentifikasi dengan beberapa kata diantaranya seperti kata; beberapa, sejumlah, sebagian, semua, sebagian besar, banyak, sedikit, selalu, sering, kadangkadang, dan lain sebagainya.

Dialog 15

PMMP Kalau kredit bisa diituang samo urang leasingnyo, Apak nio DP apak bara?

\footnotetext{
15 KBBI, Kamus Besar Bahasa Indonesia (Jakarta: Departemen Pendidikan dan Kebudayaan,).
} 
Betari Anindya, Ike Revita, dan Gusdi Sastra:

Jenis implikatur percakapan antara pramuniaga mobil Mitsubishi dengan konsumen di Kota

'Kalau kredit bisa dihitung sama orang leasingnya, Bapak mau uang mukanya berapa?'

KL Dpnyo bara ko Buk?

'Uang mukanya berapa Buk?'

PMML Sekitar 70anlah Pak

'Sekitar Rp.70.000.000,- lah Pak'

KL $\quad 70$ yo

'Rp.70.000.000,- ya'

PMML Iyo Pak

'Iya Pak'

Sesuai dengan data di atas maka KL dengan PMMP sedang membicarakan mengenai uang muka untuk mobil yang ingin ia beli. Berdasarkan konteks yang terjadi KL ingin membeli sebuah mobil Mitsubishi Xpander namun ia masih ragu ingin membeli mobil Mitsubishi Xpander dengan tipe yang mana. Dalam hal ini ia mendatangin ruang pameran untuk mendiskusikan dan mencari informasi terkait mobil Mitsubishi Xpander yang ia inginkan.

Pada data di atas terlihat bahwa KL menanyakan mengenai jumlah uang muka untuk proses inden mobil Mitsubishi Xpander. Tanggapan PMMP di atas melanggar maksim kerja sama yaitu maksim kuantitas. Tanggapan PMMP terhadap pertanyaan $\mathrm{K}$ yang menanyakan tentang jumlah uang muka mobil Mitsubishi Xpander tidaklah informatif. PMMP tidak memberikan informasi yang jelas mengenai jumlah uang muka untuk inden mobil tersebut.

Pelanggaran maksim kerjasama inilah yang menyebabkan terbentuknya sebuah tuturan implikatur yang ditandai oleh tuturan 'Sekitar 70anlah Pak'. Kata 'sekitar' menimbulkan sebuah implikasi yaitu kurang lebih. Dalam KBBI (2008) sekitar adalah sekeliling, berkisar pada, mengenai, dan kurang lebih. Oleh karena itu maka kata 'sekitar' pada data percakapan tidak memiliki kepastian dan ketidakjelasan rujukan jumlah atau angka sehingga dapat dikategorikan kepada implikatur percakapan skala. Adapun maksud yang ingin disampaikan pada data di atas adalah sebagai berikut.

Dialog 16

KL Jadi, ndak ado Xpander ko yang solar do yo Buk?

'Jadi, tidak ada mobil Mitsubishi Xpander yang solar ya Buk?'.

PMML Yang solar pajero Pak 'Yang solar mobil pajero Pak'

KL Pajero tu maha agonyo, bara kini tu?

'Pajero tu mahal harganya, berapa harganya sekarang?'

PMML Sekitar 500 kini Pak

'Sekitar Rp.500.000.000,sekarang Pak'

$\mathrm{KL}$

Alah naiak kini

'Sudah naik sekarang'

Seorang KL mendatangi ruang pameran mobil Mitsubishi dan menghampiri PMML untuk menanyakan Mobil Mitsubishi Xpander. PMML ingin melakukan meninjau mobil yang diinginkannya. Untuk itu, PMML membawa KL untuk melihat mobil Mitsubishi secara langsung. Berdasarkan percakapan di atas, terlihat KL dan PMML sedang membahas mengenai bahan bakar mobil Mitsubihsi Xpander hingga harga mobil Mitsubishi Pajero.

Pada data percakapan di atas terlihat bahwa PMML tidak mengikuti maksim kuantitas. Tanggapan yang diberikan oleh PMML tidak informatif sehingga percakapan menjadi kurang efektif. Untuk membuat percakapan menjadi efektif PMML perlu memberikan tanggapan dengan memberikan informasi yang jelas mengenai harga mobil Mitsubishi Pajero. Pelanggaran maksim kuantitas inilah 
menyebabkan timbulnya tuturan berimplikasi yang disebut sebagai implikatur.

Pada data di atas terlihat adanya implikasi pada tanggapan yang diberikan oleh PMMP kepada KP terkait harga mobil Mitsubishi Pajero. Setelah dilakukannya analisis terhadap tuturan tersebut, maka tuturan tersebut berjenis implikatur skala yang ditandai dengan tuturan 'Sekitar 500 kini Pak'. Seperti halnya dialog 5, kata 'sekitar' dapat berimplikasi kepada 'kurang lebih'. Dengan demikian maka kata 'sekitar' pada percakapan tidak memiliki kejelasan. Jika dikaitkan kepada data percakapan maka PMML secara eksplisit tidak memberikan kejelasan informasi tepat mengenai harga mobil Mitsubishi Pajero kepada KL.

Dialog 19

KP Oh masih inden, berapa lama datangnya?

'Oh masih inden, berapa lama datangnya?'

\section{PMMP Kalau yang Exceed itu sekitar 3} sampai 4 bulan.

'Kalau yang Exceed itu sekitar 3 sampai 4 bulan'.

KP Tipenya yang paling tinggi apa?

'Tipenya yang paling tinggi apa?'

PMMP Tipenya kalo yang otomatis ultimate paling tinggi, kalau yang manual Exceed paling tinggi

Bang.

'Tipenya kalo yang otomatis itu

Ultimate paling tinggi sementara kalau yang manual Exceed paling tinggi Bang'.

Berdasarkan data di atas terlihat seorang KP menanyakan harga salah satu mobil Mitsubshi. KP hendak mencari informasi dan meninjau mobil yang ia inginkan. Untuk itu ia menanyakan kepada
PMMP beberapa informasi yang ia butuhkan.

Pada percakapan di atas KP menanyakan mengenai jangka waktu inden mobil Mitsubishi Xpander. Adapun PMMP menanggapi pertanyaan tersebut dengan menggunakan tuturan berimplikasi. Hal ini menyimpulkan bahwa PMMP tidak mengikuti maksim kuantitas. Pada percakapan terlihat bahwa PMMP tidak memberikan informasi yang jelas atau tepat mengenai jangka waktu inden yang dibutuhkan untuk mobil Mitsubishi Xpander. Adapun PMMP menanggapi pertanyaan tersebut dengan sebuah tuturan berimplikasi sehingga membentuk sebuah tuturan implikatur.

Setelah dilakukannya analisis terhadap data di atas maka data di atas mengandung implikatur percakapan skala. Hal tersebut ditandai oleh tuturan 'Kalau yang Exceed itu sekitar 3 sampai 4 bulan' dialog di atas mengandung makna yang berkaitan dengan ketidakpastiam dam ketidakjelasan rujukan harga mobil Mitsubishi Xpander. Kata 'sekitar' pada tuturan di atas menciptakan implikasi 'kurang lebih', 'lebih kurang', 'antara', 'seputar'. berdasarkan hal tersebut maka kata 'kurang lebih, 'lebih kurang', 'antara', 'seputar' mengimplikasikan sesuatu yang tidak pasti.

\section{Simpulan}

Berdasarkan hasil analisis data pada percakapan antara pramuniaga mobil Mitsubishi dengan konsumen di Kota Padang. ditemukan 4 jenis implikatur pada percakapan antara pramuniaga mobil Mitsubishi dengan konsumen di Kota Padang, yaitu implikatur percakapan umum; implikatur percakapan khusus; implikatur percakapan skala; dan implikatur percakapan konvensional. Tuturan impliaktur tersebut digunakan oleh pramuniaga atau konsumen untuk 
Betari Anindya, Ike Revita, dan Gusdi Sastra:

Jenis implikatur percakapan antara pramuniaga mobil Mitsubishi dengan konsumen di Kota

menyampaikan maksud tertentu yang tidak dapat disampaikan secara langsung. Dari beberapa jenis implikatur yang ditemukan maka jenis implikatur yang sering muncul dalam percakapan pramuniaga mobil Mitsubishi dengan konsumen di kota Padang adalah jenis implikatur percakapan umum. Hal ini karena antara pramuniaga mobil Mitsubishi dengan konsumen cenderung menggunakan konteks percakapan umum dalam berkomunikasi. Adapun konteks percakapan khusus hanya digunakan pada saat tertentu.

\section{Daftar Pustaka}

Budiawan, Aito Harry. "Mobil Mobil Terlaris Di Awal Tahun 2018 Dalam Sebuah Berita Otomotif.," metrotvnews.com diakses pada tanggal Mei , Pukul 08.00 WIB 2018, parag 5.

Grice, H. Paul. Ligic and Conversation in P. Cole and J.L Morgan Eds, Syntax and Semantics. Vol. Vol. 3. New York: Academic Press, 1975.

KBBI. Kamus Besar Bahasa Indonesia. Jakarta: Departemen Pendidikan dan Kebudayaan, 2008.

Mulyana. Implikatur Dalam Kajian Pragmatik DIKSI 8 (9): 53-63. Dalam Sebuah Jurnal Ebookbrowse.Com Diakses 13 Desember 2017, Pukul 09.00 WIB. diakses pada tanggal 13 Desember 2017, Pukul 09.00 WIB, n.d. ebookbrowse.com.

Nanda. "Conversational Implicature of the Presenters in Take ME Out Indonesia." Conaplin Journal Vol. 1 No. 2 (n.d.): Hlm 120-138.

Nugraheni, Yunita. "Analisis Implikatur Pada Naskah Film Harry Potter and The Goblet of Fire." Semarang Universitas Muhammadiyah, 2010.
Odgen, C.K., and L.A Richards. The Meaning of Meaning. London: ARK Paperbacks, 1923.

Prayogi, Gesit. "Mitsubishi Indonesia Dapat Pesanan 3,8 Ribu Unit Xpander Dari Filipina." Uzone.Id Diakses Pada Tanggal 25 Mei 2018 Pukul 08.00, 2018.

Revita, Ike. Pragmatik (Kajian Tindak Tutur Permintaan Lintas Bahasa. Padang: FIB Universitas Andalas, 2013.

Rustono. Pokok-Pokok Pragmatik. Semarang: CV IKIP Semarang Press, 1999.

Sudaryanto. Metode Linguistik: Ke Arah Memahami Metode Linguistik. Yogyakarta: Gadjah Mada University Press, 2015.

Wijana, I Dewa Putu. Dasar-Dasar Pragmatik. Yogyakarta: Andi, 1963.

Yule, George. The Study of Language. Cambridge: Cambridge University Press, 2010. 